
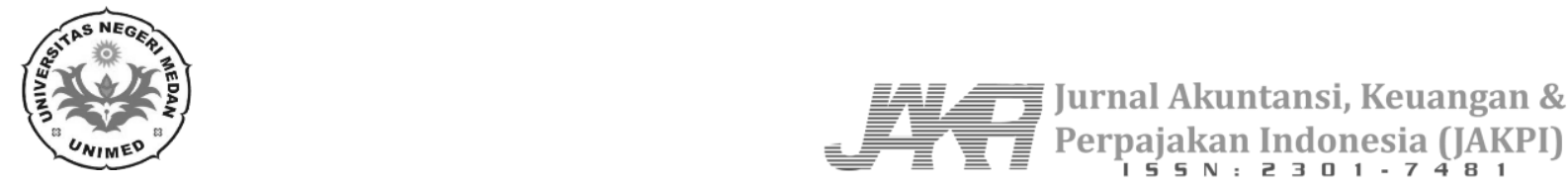

\title{
Analisis Pengaruh Faktor-Faktor Fundamental terhadap Harga Saham pada Bank - Bank Plat Merah tahun 2008-2018
}

\author{
Firnanda Novita R, Maureen Inesella LT, David Kaluge \\ Universitas Brawijaya Malang \\ Email :firnanda.novita@ymail.com
}

\begin{abstract}
Abstrak :Pasar modal sebagai sarana investor dalam menjual dan membeli saham (stock) dan obligasi (bond), dimana perusahaan itu memiliki tujuan bahwa hasil penjualan saham itu bisa dimanfaatkan untuk memperkuat dana perusahaan. Penilaian harga saham secara akurat bisa meminimalkan resiko sekaligus membantu investor mendapatkan keuntungan, mengingat investasi saham di pasar modal merupakan jenis investasi yang beresiko tinggi meskipun menjanjikan keuntungan relatif besar.Faktor-faktor fundamental yang diwakili oleh kinerja keuangan menjadi sumber informasi sebagai bahan pertimbangan dalam keputusan investor.Tujuan penelitian ini adalah untuk mengetahui bagaimana pengaruh faktor-faktor fundamental secara parsial dan simultan terhadap harga saham pada Bank - Bank Plat Merah pada tahun 2008-2018.Variabel yang digunakan dalam penelitian ini adalah faktor-faktor fundamental yang diwakili kinerja keuangan sebagai variabel independen dan harga saham sebagai variabel dependen. Kinerja keuangan diukur dengan Earning per Share (X1), Price Earning Ratio (X2), Price to Book Value (X3), Return to Equity (X4) dan Debt to Equity Ratio (X5) serta harga saham (Y). Metode penelitian yangdigunakan adalah model data panel. Data yang digunakan dalam penelitian ini adalah data pooling, yang merupakan kombinasi antara data cross section dan data time series yang diambil dari laporan keuangan tahunan bank-bank plat merah yaitu Bank Mandiri, Bank BRI, Bank BNI dan Bank BTN serta data harga saham yang diambil dari Bursa Efek Indonesia. Pengujian data dilakukan dengan menggunakan analisis statistik yaitu analisis data panel, uji t dan uji F. Uji t digunakan untuk mengguji pengaruh variabel independen secara parsial terhadap variabel dependen. Uji $\mathrm{F}$ digunakan untuk menguji pengaruh variabel independen secara bersama-sama terhadap variabel dependen.Hasil penelitian menunjukkan bahwa variabel independen, faktor-faktor fundamental yang diwakili kinerja keuangan secara bersama-sama berpengaruh signifikan terhadap harga saham. Faktor - faktor fundamental yang diwakili oleh variabel EPS, PBV, ROE, dan DER berpengaruh signifikan secara parsial terhadap harga saham, sedangkan variabel PER tidak berpengaruh signifikan secara parsial terhadap harga saham pada Bank-Bank Plat Merah pada tahun 2008-2018.
\end{abstract}

Kata kunci :Faktor-Faktor Fundamental, Kinerja Keuangan, Harga Saham 


\section{Pendahuluan}

Pasar modal adalah suatu tempat bertemunya berbagai pihak perusahaan yang akan menjual saham (stock) dan obligasi (bond), dimana perusahaan itu memiliki tujuan bahwa nantinya dari hasil penjualan saham itu bisa dimanfaatkan untuk memperkuat dana perusahaan (Fahmi,2009:41). Fungsi pasar modal adalah sebagai sarana untuk pengumpulan dana yang berasal dari masyarakat umum yang kemudian diinvestasikan di pasar modal yang memiliki tujuan untuk mencari keuntungan yang akan berguna untuk memajukan perusahaannya dan membantu mendukung perekonomian suatu negara.

Bursa Efek Indonesia (BEI) adalah salah satu lembaga pasar modal yang terbentuk melalui penggabungan (merger) antara Bursa Efek Jakarta dan Bursa Efek Surabaya. Berdasarkan data yang dihimpun dari Bursa Efek Indonesia (BEI), sampai dengan akhir tahun 2018, BBRI (PT Bank Rakyat Indonesia Tbk.) merupakan perusahaan yang mencatatkan keuntungan paling besar, yakni senilai Rp32 Triliun. Sedangkan 3 bank plat merah lainnya seperti PT Bank Mandiri (Persero) Tbk (BMRI), PT Bank Negara Indonesia (Persero) Tbk (BBNI) dan PT Bank Tabungan Negara (Persero) Tbk (BBTN) juga memiliki keuntungan laba bersih sebesar dua digit antara 12-20\% meskipun tidak sebesar Bank BRI. Tingkat rata-rata laba perusahaan LQ45 bertumbuh sebesar 12\% sepanjang tahun 2018. Namun, hal ini tidak disertai dengan peningkatan permintaan di pasar modal dimana pasar modal mencatatkan pelemahan sebesar $2,5 \%$.

Ketika laba perusahaan naik, tetapi harga saham menurun disebabkan oleh faktor eksternal yang terjadi pada perekonomian dunia, di antaranya kenaikan suku bunga The Federal Reserves (Bank Sentral Amerika), risiko terjadinya perang dagang antara Amerika Serikat dan China, serta pelemahan ekonomi global. Kenaikan suku bunga The Fed yang agresif pada 2017 dan 2018 menyebabkan arus dana asing yang dulunya masuk ke Indonesia pada masa Quantitative Easing pada 2008 menjadi berubah haluan dan keluar dengan deras. Tercatat, dana asing keluar sebanyak Rp40 triliun pada 2017 dan Rp50 triliun pada tahun 2018 dan secara kumulatif arus dana asing yang keluar mencapai lebih dari Rp90 triliun dalam 2 tahun tersebut. Sedangkan dalam periode yang sama, emiten-emiten di (Bursa Efek Indonesia) BEI mencatatkan pertumbuhan laba.

Sebagai investor, data laba perusahaan sangat berguna dalam pengambilan keputusan investasi dikarenakan perusahaan yang labanya bertumbuh, biasanya akan diikuti juga oleh harga saham yang ikut bertumbuh. Penetapan harga saham di pasar modal selalu mengalami perubahan, maka dari itu investor harus mampu memperhatikan faktor-faktor yang memengaruhi harga saham.Harga suatu saham dapat ditentukan menurut hukum permintaan dan penawaran.Semakin banyak yang membeli suatu saham, maka harga saham cenderung bergerak naik. Selain itu suatu berita yang ada di pasar modal, misalnya keadaan keuangan suatu perusahaan akan mempengaruhi harga saham yang ditawarkan kepada masyarakat umum dan jenis-jenis informasi lainnya bisa mempengaruhi profitabilitas suatu perusahaan di masa depan.

Penilaian saham secara akurat bisa meminimalkan resiko sekaligus membantu investor mendapatkan keuntungan, mengingat investasi saham di pasar modal merupakan jenis investasi yang beresiko tinggi meskipun menjanjikan keuntungan relatif besar. Ketika seorang investor merupakan pemodal yang bersifat rasional maka aspek fundamental menjadi suatu dasar dari penilaian pertama seorang fundamentalis, dengan kata lain nilai suatu saham menjadi patokan yang mewakili nilai suatu perusahaan untuk mencapai harapan yang diinginkan perusahaan dalam meningkatkan nilai kekayaan di masa depan.

Kinerja keuangan menjadi sumber informasi sebagai bahan pertimbangan dalam memutuskan investasi ini menjadi hal yang amat penting (Tiningrum,2012). Kinerja keuangan yang baik akan dijadikan patokan oleh para investor dalam melakukan investasi diperusahaan yang bersangkutan, yang akan berdampak pada semakin baiknya kinerja keuangan yang diperoleh dan semakin besar juga kepercayaan yang diberikan oleh investor terhadap perusahaan yang bersangkutan.

Dalam penelitian ini, faktor-faktor fundamental yang diwakili oleh kinerja keuangan perusahaan diukur dengan Earning per Share (EPS), market rasio yang diukur dengan Price Earning Ratio (PER), Price to Book Value (PBV), rasio profitabilitas yang dapat diukur denganReturn On Equity (ROE), danrasio Solvabilitas yang diwakili oleh Debt to Equity Ratio 
(DER) sehingga penulis mengambil judul "Analisis Pengaruh Faktor-Faktor Fundamental terhadap Harga Saham Pada Bank - Bank Plat Merah pada tahun 2008-2018.”

\section{Tinjauan Pustaka}

\section{Pasar Modal sebagai Sarana Penentu Harga Saham}

Pasar modal merupakan sarana atau wadah untuk mempertemukan antara penjual dan pembeli. "Pasar modal merupakan situasi yang mana memberikan ruang dan peluang penjual dan pembeli bertemu dan bernegoisasi dalam pertukaran komuditas dan kelompok komuditas modal (Hadi, 2013:10). Modal disini berupa modal hutang (obligasi) maupun modal ekuitas (equity). Tandelilin (2010:26) menerangkan bahwa pasar modal adalah pertemuan antara pihak yang memiliki kelebihan dana dengan pihak yang membutuhkan dana dengan cara memperjualbelikan sekuritas. Lubis (2008:7) menyatakan bahwa pada dasarnya pasar modal hampir sama dengan pasar-pasar lain, terdapat penjual dan pembeli. Jika jumlah orang yang ingin membeli lebih banyak dibandingkan dengan yang ingin menjual, maka harga akan semakin tinggi dan bila tidak ada seorangpun yang membeli dan banyak yang menjual maka harga akan menurun.

Saham adalah tanda bukti memiliki perusahaan dimana pemiliknya disebut juga sebagai pemegang saham. Menurut Darmadji dan Hendi (2006:178) saham dapat didefiniskan sebagai tanda atau pemilikan seseorang atau badan dalam suatu perusahaan atau perseroan terbatas. Nilai pasar saham menurut Sunariyah (2006:128) adalah harga suatu saham pada pasar yang sedang berlangsung di bursa efek. Apabila saham mengalami kelebihan permintaan, maka harga saham cenderung naik. Begitupula sebaliknya, apabila kelebihan penawaran maka harga saham cenderung turun.

\section{Kinerja Keuangan sebagai Bagian dari Analisis Fundamental yang Mengukur Keberhasilan Perusahaan}

Analisis fundamental adalah analisis memperkirakan harga saham di masa yang akan datang dengan mengestimasi nilai faktor-faktor fundamental yang mempengaruhi harga saham di masa yang akan datang dan menerapkan hubungan variabel-variabel tersebut sehingga diperoleh taksiran harga saham (Husnan, 2003:303). Fundamental secara umum terdapat dua macam yaitu internal (perusahaan berupa data keuangan) dan eksternal (ekonomi/pasar dan industri berupa kebijakan pemerintah, tingkat suku bunga,inflasi dan sebagainya).

Menurut Munawir (2010:30), kinerja keuangan perusahaan merupakan satu diantara dasar penilaian mengenai kondisi keuangan perusahaan yang dilakukan berdasarkan analisa terhadap rasio keuangan perusahaan. Rasio-rasio keuangan inilah yang menggambarkan kinerja keuangan dari suatu perusahaan. Berikut rasio keuangan yang digunakan dalam penelitian ini, yaitu :

\section{Earning Per Share (EPS)}

Earning Per Share (EPS) menurut Kasmir (2012:207) merupakan "Rasio untuk mengukur keberhasilan manajemen dalam mencapai keuntungan bagi pemegang saham." Semakin tinggi nilai EPS tentu saja menggembirakan pemegang saham karena semakin besar laba yang disediakan untuk pemegang saham. Rasio laba menunjukkan dampak gabungan dari likuiditas serta manajemen aktiva dan kewajiban terhadap kemampuan perusahaan menghasilkan laba. Jadi, disimpulkan bahwa EPS merupakan suatu rasio yang menunjukkan jumlah laba yang didapatkan dari setiap lembar saham yang ada.

Berikut rumus dalam menghitung EPS menurut Kasmir (2012:207) yaitu:

$$
E P S=\frac{E A T-\text { Dividen Saham Preferen }}{\text { Total saham yang diterbitkan }}
$$

\section{Price Eraning Ratio (PER)}

Menurut Bringham dan Hoiston (2010:150), Price Earning Ratio adalah "harga saham terhadap laba per saham menunjukkan jumlah yang rela dibayarkan oleh investor untuk setiap dolar laba yang dilaporkan”. Sedangkan menurut Jogianto (2003:105) Price 
Earning Ratio adalah "rasio harga saham terhadap Price Earning Ratio lain dengan kata lain menunjukkan seberapa besar pemodal menilai harga saham terhadap kelipatan dari Earnings".

Berikut rumus dalam menghitung PER yaitu:

$$
P E R=\frac{\text { Harga Saham }}{\text { Laba per Lembar Saham }}
$$

\section{Price to Book Value (PBV)}

Menurut Ang (1997) dalam Novitasari (2013) Price to Book Value (PBV) merupakan rasio pasar (market ratio) yang digunakan untuk mengukur kinerja harga pasar saham terhadap nilai bukunya. Rasio ini menunjukkan seberapa jauh sebuah perusahaan mampu menciptakan nilai perusahaan terhadap jumlah modal yang diinvestasikan.

Berikut rumus menghitung PBV yaitu:

$$
P B V=\frac{\text { Harga Saham }}{\text { Nilai Buku per Lembar Saham }}
$$

\section{Return On Equity (ROE)}

Return On Equity (ROE), karena rasio ini menunjukkan kesuksesan manajeman dalam memaksimalkan tingkat kembalian pada pemegang saham. Return On Equity merupakan salah satu variabel yang terpenting yang dilihat investor sebelum mereka berinvestasi. ROE menunjukan kemampuan perusahaan untuk menghasilkan laba setelah pajak dengan menggunakan modal sendiri yang dimiliki perusahaan. Investor yang akan membeli saham akan

tertarik dengan ukuran profitabilitas ini, atau bagian dari total profitabilitas yang bisa dialokasikan ke pemegang saham. Hanafi dan Halim (2012:177).

Berikut rumus dalam menghitung ROE yaitu:

$$
R O E=\frac{\text { Laba Setelah Pajak }}{\text { Ekuitas Pemegang Saham }}
$$

\section{Debt to Equity Ratio (DER)}

Menurut Prastomo (2002:84) dalam Williana (2012), "Debt to Equity Ratio (DER) dapat memberikan gambaran mengenai struktur modal yang dimiliki oleh perusahaan, sehingga dapat dilihat tingkat resiko tertagihnya suatu utang." Kasmir (2012:158) menjelaskan bahwa "Hasil dari rasio ini akan memberikan arti yang berbeda bagi kreditor dan perusahaan. Bagi Bank (kreditor), semakin besar rasio ini akan semakin tidak menguntungkan, karena semakin besar resiko yang ditanggung atas kegagalan yang mungkin terjadi di perusahaan".

Berikut rumus menghitung DER yaitu:

$$
D E R=\frac{\text { Total Hutang }}{\text { Ekuitas Pemegang Saham }}
$$

\section{Signalling Theory sebagai Tanda dalam Pengambilan Kebijakan Perusahaan}

Signalling Theory atau teori sinyal dikembangkan oleh Ross (1977) menyatakan bahwa pihakeksekutif perusahaan memiliki informasi lebih baik mengenai perusahaannya akan terdorong untuk menyampaikan informasi tersebut kepada calon investor agar harga saham perusahaannya meningkat. Signalling theory adalah teori yang membahas tentang tanda-tanda yang tergambarkan dalam setiap berbagai kebijakan yang dilakukan oleh perusahaan, khususnya pada perusahaan yang go public, dan tanda-tanda tersebutlah yang ditangkap oleh pihak investor sebagai salah satu pendukung dalam pengambilan keputusannya (Fahmi, 2015:172). Sinyal 
diberikan kepada calon investor dengan cara menerbitkan prospectus oleh perusahaan. Prospectus ini berisikan tentang informasi financial dan non financial dari perusahaan yang bersangkutan. Informasi yang dijelaskan dalam prospectus akan membantu para investor dalam membuat keputusan mengenai risiko nilai saham sesungguhnya yang ditawarkan oleh perusahaan secara rasional.

\section{Penelitian Terdahulu}

Berikut penelitian terdahulu yang sesuai dengan penelitian ini, yaitu :

1. Martina (2019) meneliti Pengaruh DER, ROA, ROE, EPS dan MVA terhadap Harga Saham dalam Indeks Saham Syariah Indonesia pada perusahaan manufaktur, yang hasilnya menunjukkan Earning Per Share (EPS) dan Market Value Added (MVA) memiliki efek positif pada harga saham, tetapi hasil yang berbeda untuk variabel Debt to Equity Ratio, Return OnAssets dan Return On Equity yang secara parsial tidak berpengaruh terhadap harga saham.

2. Gabriella (2018) menganalisis Pengaruh Struktur Modal dan ROA terhadap Harga Saham pada Food And Beverages Industry yang Terdaftar DI BEI (Tahun 2014-2016), yang hasilnyamenunjukkan sacara simultan DER dan ROA tidak memiliki pengaruh signifikan terhadap Closing Price (Close). Secara parsial DER tidak memiliki pengaruh signifikan terhadap Closing Price (Close), dan ROA juga tidak memiliki pengaruh signifikan terhadap Closing Price (Close).

3. Lasni (2009) yang menganalisis mengenai faktor fundamental dan risiko sistematik terhadap harga saham pada industri dasar dan kimia di BEI, yang hasil penelitiannya menunjukkan bahwa ROE dan PER itu secara parsial tidak mempengaruhi harga saham dan secara simultan ROE mempengaruhi harga saham. Berdasarkan hasil penelitian sebelumnya, pastilah memiliki tujuan dan manfaat tersendiri bagi sebuah perusahaan baik dalam hal keuangan perusahaan maupun dalam hal pengambilan keputusan. Walaupun ada beberapa penelitian terdapat hasil yang berbeda-beda sehingga menimbulkan tanda tanya dan perdebatan mengenai hasil mana yang benar-benar terbukti benar. Sehingga bisa membantu sebuah perusahaan menjalankan perusahaannya dengan baik.

4. Daniarto (2013) meneliti tentang Analisis Pengaruh Faktor-Faktor Fundamental Rasio Keuangan terhadap Perubahan Harga Saham, yang hasilnya variabel fundamental diwakili pada rasio

keuangan ROE, ROA, DER, CR, EPS, dan BVS secara simultan berpengaruh signifikan terhadap perubahan harga saham. Berdasarkan hasil uji-t, secara terpisah menunjukkan hanya variabel CR yang berpengaruh signifikan terhadap perubahan harga saham sedangkan variabel yang lainnya tidak berpengaruh signifikan.

Hasil penelitian sebelumnya yang dilakukan oleh beberapa peneliti antara lain Martina (2019), Gabriella (2018), Lasni (2009) dan Daniarto (2013) masih perlu ditinjau lebih jauh lagi.

\section{Metode Penelitian}

Dalam penelitian ini, jenis penelitian yang digunakan adalah pendekatan kuantitatif. Jenis penelitian kuantitatif adalah penelitian yang menggunakan data yang berbentuk angkaangka atau data kualitatif yang diangkakan dan analisis menggunakan statistik (Sugiyono, 2010). Populasi dalam penelitian ini adalah perusahaan perbankan yang listing saham di Bursa Efek Indonesia. Jumlah populasi adalah 39 perusahaan perbankan. Teknik pengambilan sampel yang digunakan dalam penelitian ini adalah metode purposive sampling. Pemilihan sampel ini didasarkan pada kriteria bank plat merah di Indonesia.

Data yang dikumpulkan adalah data sekunder yang didapatkan secara tidak langsung dari sumber utama yaitu perusahaan. Sumber data yang digunakan dari laporan keuangan dan harga saham pada website perusahaan dan Bursa Efek Indonesia. Data yang dikumpulkan dalam penelitian ini menggunakan teknik dokumentasi dengan cara melakukan pencatatan, menyalin dari penelitian sebelumnya. Selain itu untuk data harga saham diambil dari www.idx.co.iddan laporan keuangan bank diambil dari website resmi dari Bank Mandiri yaitu www.mandiri.co.id, 
Bank BRI yaitu www.bri.co.id, Bank BNI yaitu www.bni.co.iddan Bank BTN yaitu www.btn.co.id.

\section{Metode Analisis}

Metode yang digunakan dalam penelitian ini adalah data panel. Model regresi data panel bertujuan untuk memprediksi parameter model regresi yaitu nilai intercept atau konstanta dan slope atau koefisien regresi. Penggunaan data panel dalam regresi akan menghasilkan intercept dan slope yang berbeda pada setiap perusahaan dan setiap periode waktu. Menurut Widarjono (2007 : 251), untuk mengestimasi parameter model dengan data panel terdapat tiga teknik yaitu :

1. Common Effect Model. Teknik yang paling sederhana untuk mengestimasi parameter model datapanel yakni dengan mengkombinasikan data cross section dan time series sebagai satu kesatuan tanpa melihat adanya perbedaan waktu dan individu. Pendekatan ini menggunakan metode OrdinaryLeast Square (OLS).

2. Fixed Effect Model. Teknik ini mengestimasi data panel dengan menggunakan variabel dummyuntuk menangkap adanya perbedaan intercept. Pendekatan ini didasarkan pada perbedaan intercept antara perusahaan namun interceptnya sama antar waktu. Model ini mengasumsikan slope tetap antar perusahaan dan antar waktu dengan menggunakan metode Least Square Dummy Variabel (LSDV).

3. Random Effect Model. Teknik ini mengestimasi data panel dimana variabel gangguan salingberhubungan antar waktu dan antar individu dan perbedaan ini diakomodasi dengan error. Karena adanya korelasi antar variabel gangguan maka metodel OLS tidak dapat digunakan sehingga model Random Effect menggunakan metode Generalized Least Square (GLS).

Teknik untuk memilih estimasi data panel yaitu :

a. Uji chow adalah pengujian untuk menentukan model fixed effect atau common effect yang paling tepat digunakan dalam mengestimasi data panel. Pengambilan keputusannya jika:

- $\quad$ Nilai prob. $\mathrm{F}<$ batas kritis, maka tolak H0 atau memilih fixed effect dari pada common effect.

- Nilai prob. F > batas kritis, maka terima H0 atau memilih common effect dari pada fixed effect.

b. Uji hausman, adalah pengujian statistik untuk memilih apakah model fixed effect atau random effect yang paling tepat digunakan. Pengambilan keputusan dilakukan jika:

- Nilai probabilitas chi squares< taraf signifikansi, maka tolak H0 atau memilih fixed effect dari pada random effect.

- Nilai probabilitas chi squares $>$ taraf signifikansi, maka tidak menolak H0 atau memilih randomeffect dari pada fixed effect.

Model persamaan dalam penelitian ini mengingat data panel merupakan gabungan dari data cross section dan data time series, yaitu :

Dimana :

$$
Y_{i t}=\propto+\beta_{1} X_{1 i t}+\beta_{2} X_{2 i t}+\beta_{3} X_{3 i t}+\beta_{4} X_{4 i t}+\beta_{5} X_{5 i t}+\varepsilon_{i t}
$$

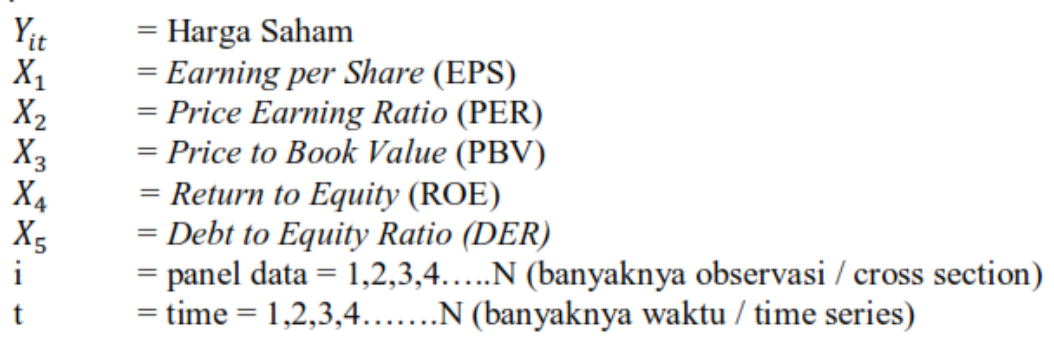

Setelah dilakukan pengujian Fixed Effect Model kemudian dilakukan pula Uji Asumsi Klasik. Uji Asumsi Klasik adalah pengujian asumsi-asumsi statistik yang harus dipenuhi pada analisis regresi linear berganda yang berbasis Ordinary Least Square (OLS). Asumsi klasik yang digunakan diantaranya : 


\section{Uji Normalitas}

Uji normalitas merupakan pengujian terhadap kenormalan distribusi data. Jika suatu residual model tidak terdistribusi normal, maka uji t kurang relevan digunakan untuk menguji koefisien regresi. Uji normalitas dapat dilakukan dengan beberapa metode yaitu histogram residual, kolmogrov smirnov, skewness kurtosius dan jarque - bera. Hipotesis pengujian ini yaitu :

H0: Probabilitas Jaque-Bera > signifikansi, residual berdistribusi normal.

H1: Probabilitas Jaque-Bera < signifikansi, residual tidak berdistribusi normal.

2. Uji Autokorelasi

Autokorelasi adalah korelasi yang terjadi antar observasi dalam satu variabel (Nachrowi dan Hardius, 2006:183). Dengan adanya autokorelasi, estimator OLS tidak menghasilkan estimator yang BLUE hanya LUE (Widarjono, 2007:258). Metode untuk mendeteksi autokorelasi antara lain metode grafik, durbin-watson, run dan lagrange multiplier.Untuk mengetahui adanya autokorelasi dalam suatumodel regresi dilakukan melalui pengujian terhadap nilai Durbin Watson dengan asumsi :

H0 : Tidak terdapat Autokorelasi

H1 : Terdapat Autokorelasi

\section{Uji Multikolinearitas}

Multikolinieritas dilakukan pada saat model regresi menggunakan lebih dari satu variabel bebas. Multikolinearitas berarti adanya hubungan linear di antara variabel bebas (Nachrowi dan Hardius, 2006:95). Dampak adanya multikolinieritas adalah banyak variabel bebas tidak signifikan mempengaruhi variabel terikat namun nilai koefisien determinasi tetap tinggi. Metode untuk mendeteksi multikolinearitas antara lain variance influence factor dan korelasi berpasangan.

4. Uji Heteroskedastisitas

Uji heteroskedastisitas digunakan untuk melihat apakah residual dari model yang terbentuk memiliki varians yang konstan atau tidak. Uji heteroskedastisitas penting dilakukan pada model yang terbentuk. Dengan adanya heteroskedastisitas, hasil uji t dan uji F menjadi tidak akurat (Nachrowi dan Hardius, 2006:112). Metode untuk mendeteksi heteroskedastisitas antara lain metode grafik, park, glesjer, korelasi spearman, goldfeld-quandt, breusch-pagan dan white. Uji heteroskedastisitasmenggunakan grafik maupun uji informal lainnya karena tanpa adanya angka statistik penafsiran tiap orang berbeda terhadap hasil pengujian. Berikut hipotesis uji heteroskedastisitasnya :

H0 : Probabilitas Chi-Square $>\alpha(5 \%)$, tidak ada heteroskedastisitas

H1 : Probabilitas Vhi-Square $<\alpha(5 \%)$, ada heteroskedastisitas

Pengujian Hipotesis menggunakan Uji t dan Uji F. Uji statistik $t$ dikenal dengan uji parsial, yaitu untuk menguji bagaimana pengaruh masing-masing variabel bebasnya secara sendiri-sendiri terhadap variabel terikatnya, sedangkan Uji $F$ bertujuan untuk mengetahui pengaruh variabel independen secara bersama-sama terhadap variabel dependen dengan melihat nilai signifikansi $\mathrm{F}$. Koefisien determinasi $\left(\mathrm{R}^{2}\right)$ digunakan untuk mengukur seberapa jauh kemampuan model dalam menerangkan variasi variabel terikat. Nilai $\mathrm{R}^{2}$ yang kecil menujukkan kemampuan variabel-variabel bebas dalam menjelaskan variasi variabel terikat amat terbatas. Nilai $\mathrm{R}^{2}$ yang mendekati satu menunjukkan bahwa variabel bebas memberikan hampir semua informasi yang dibutuhkan untuk memprediksi variasi variabel dependen (terikat).

\section{Hasil Dan Pembahasan}

\section{Pemilihan Model Data Panel}

Analisis yang digunakan adalah analisis regresi data panel. Ada 3 metode dalam analisis regresi data panel yaitu Common Effect Model (Pooled Least Square), Fixed Effect Model, dan Random EffectModel. Untuk menentukan pendekatan yang digunakan pada data panel maka perlu dilakukan Uji Chow.Uji Chow digunakan untuk menentukan model Pooled Least Square atau Fixed Effect Model yang paling tepat digunakan dalam mengestimasi data panel (Widarjono,2007). Hipotesis dalam uji chow yaitu: 
H0 :Common Effect Model atau Pooled Least Square

H1 :Fixed Effect Model

Berikut ini hasil uji chow untuk menentukan manakah yang lebih tepat diantara Common Effect Model(Pooled Least Square) dan Fixed Effect Model :

Tabel 1: Uji Chow

Redundant Fixed Effects Tests

Pool: BANK

Test cross-section fixed effects

\begin{tabular}{lrrr}
\hline \hline Effects Test & Statistic & d.f. & Prob. \\
\hline Cross-section F & 4.974595 & $(3,35)$ & 0.0056 \\
Cross-section Chi-square & 15.626576 & 3 & $\mathbf{0 . 0 0 1 4}$ \\
\hline
\end{tabular}

Sumber : Hasil Olahan Eviews 9 (2019)

Berdasarkan Tabel 4.1, dari hasil Uji Chow diperoleh nilai Probabilitas Chi-Squarenya sebesar 0.0014 lebih kecil dari $\alpha=0.05$ (5\%) sehingga H0 ditolak dan H1 diterima yang berarti model yang paling tepat digunakan adalah Fixed Effect Model (FEM). Pada penelitian ini, penulis tidak melakukan Uji Hausman karena berdasarkan teori dari Nachrowi dan Usman (2006) yang telah membuktikan secara matematis, mengungkapkan bahwa Jika data panel yang dimiliki mempunyai jumlah waktu $(\mathrm{T})$ lebih besar dibanding jumlah individu (N) maka disarankan untuk menggunakan metode Fixed Effect Model.

\section{Hasil Analisis Dengan Menggunakan Uji Asumsi Klasik}

Uji Asumsi Klasik adalah pengujian asumsi-asumsi statistic yang harus dipenuhi pada analisis regresi linear berganda yang berbasis Ordinary Least Square (OLS).Fixed Effect Model menggunakan pendekatan Ordinary Least Square (OLS) sehingga perlu dilakukan Uji Asumsi Klasik.

\section{Uji Normalitas}

Uji Normalitas adalah uji statistik yang dilakukan untuk mengetahui bagaimana sebaran sebuah data. Uji normalitas digunakan untuk melihat apakah nilai residual terdistribusi normal atau tidak. Hipotesis dalam pengujian ini yaitu :

H0: Probabilitas Jaque-Bera > signifikansi, residual berdistribusi normal

H1: Probabilitas Jaque-Bera < signifikansi, residual tidak berdistribusi normal

\section{Gambar 1}

Uji Normalitas

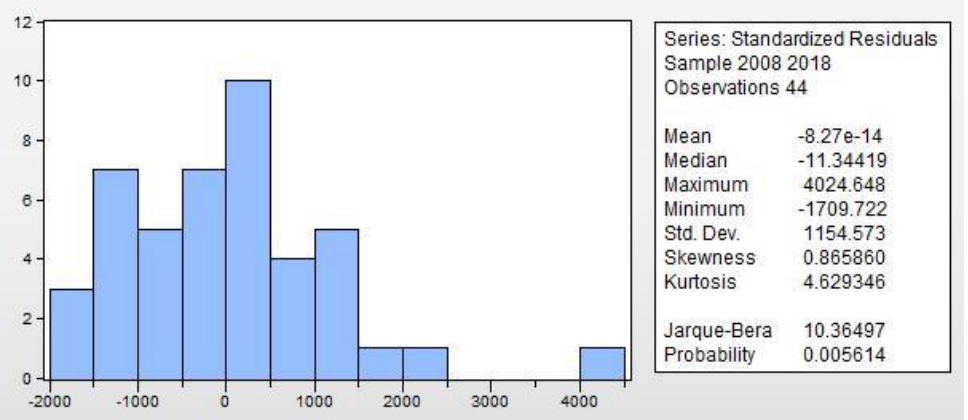

Berdasarkan hasil uji normalitas diatas, probabilitas Jaque-Bera sebesar $0.005614<\alpha=$ $0.05 \quad(5 \%)$ maka $\mathrm{H} 0$ ditolak, yangberarti residual tidak berdistribusi normal.

Sumber : Hasil Olahan Eviews 9 (2019)

\section{Uji Autokorelasi}

Autokorelasi pada model regresi artinya ada korelasi antar anggota sampel yang diurutkan berdasarkan waktu saling berkorelasi. Untuk mengetahui adanya autokorelasi dalam suatu model regresi dilakukan melalui pengujian terhadap nilai Durbin Watson dengan asumsi : 
H0: Tidak terdapat Autokorelasi

H1: Terdapat Autokorelasi

Pada regresi linear berganda, yang diharapkan adalah menerima hipotesis H0 yaitu tidak terdapat autokorelasi. Berikut hasil estimasi OLS yaitu:

Tabel 2

Hasil Fixed Effect Model-White Cross-Section SUR

\begin{tabular}{|c|c|c|c|}
\hline R-squared & 0.886897 & Mean dependent var & 5164.091 \\
Adjusted R-squared & 0.861045 & S.D. dependent var & 3433.088 \\
S.E. of regression & 1279.740 & Akaike info criterion & 17.32695 \\
Sum squared resid & 57320680 & Schwarz criterion & 17.69190 \\
Log likelihood & -372.1929 & Hannan-Quinn criter. & 17.46229 \\
F-statistic & 34.30665 & Durbin-Watson stat & $\mathbf{2 . 1 5 7 7 6 1}$ \\
Prob(F-statistic) & 0.000000 &
\end{tabular}

Sumber : Hasil Olahan Eviews 9 (2019)

Berdasarkan estimasi menggunakan metode Ordinary Least Square diketahui nilai Durbin Watson statistiknya sebesar $\mathbf{2 . 1 5 7 7 6 1}$ dibandingkan dengan perhitungan Durbin Watson statistic tabel yaitu:

Tabel 3

Perhitungan Durbin Watson Statistik

\begin{tabular}{|c|c|}
\hline Kategori & Nilai \\
\hline k' & 5 \\
\hline N & 44 \\
\hline D-W Stat & 2.157761 \\
\hline D-W Tabel pada $\alpha=5 \%$ & 1,287 \\
dU & 1,776 \\
4-dU & 2,224 \\
4-dL & 2,713 \\
\hline k' $=$ jumlah variabel bebas \\
n $=$ banyaknya observasi \\
\hline
\end{tabular}

Sumber : Hasil Perhitungan Penulis (2019)

Berdasarkan hasil estimasi dan perhitungan dengan menggunakan Tabel Durbin Watson Statistik diketahui letak DW Statistiknya yaitu:

Gambar 2

Pengujian Durbin Watson

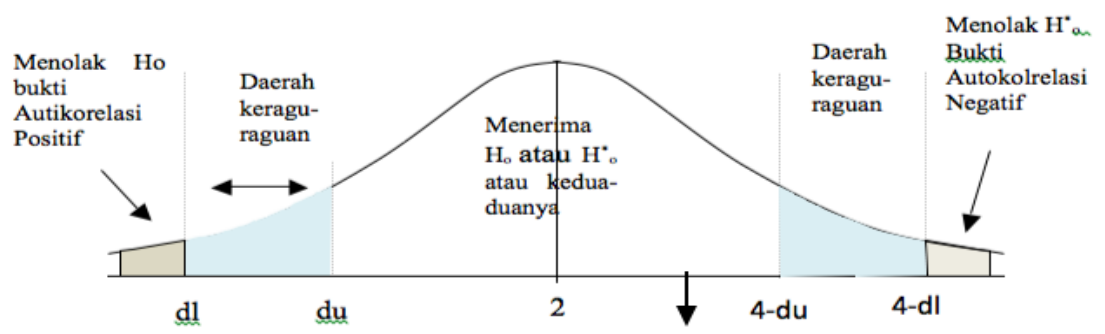

DW Stat :2.157761

Sumber : Hasil diolah (2019) 
Berdasarkan tabel Uji Autokorelasi terlihat bahwa nilai Durbin Waston sebesar 2.157761 beradapada daerah menerima hipotesis $\mathrm{H} 0$ atau tidak terdapat autokorelasi. Hal ini menunjukkan bahwamodel ini tidak mengandung masalah autokorelasi.

\section{Uji Multikolinearitas}

Uji multikolinearitas digunakan untuk melihat ada atau tidaknya korelasi yang tinggi antara variabel-variabel bebas di dalam model regresi. Berikut hasil uji multikolinearitas :

Tabel 4

Hasil Uji Multikolinearitas

\begin{tabular}{|c|c|c|c|c|c|}
\hline & EPS & PER & PBV & ROE & DER \\
\hline EPS & 1 & -0.367 & 0.483 & 0.511 & -0.482 \\
\hline PER & -0.367 & 1 & -0.008 & -0.175 & 0.112 \\
\hline PBV & 0.483 & -0.008 & 1 & 0.765 & -0.130 \\
\hline ROE & 0.511 & -0.175 & 0.765 & 1 & 0.099 \\
\hline DER & -0.482 & 0.112 & -0.130 & 0.099 & 1 \\
\hline
\end{tabular}

Sumber : Hasil Olahan Eviews 9 (2019)

Berdasarkan hasil uji multikolinearitas diketahui bahwa semua variabel memiliki nilai lebih dari 0.8 sehingga artinya tidak terjadi masalah multikolinearitas di dalam regresi.

\section{Uji Heteroskedastisitas}

Heteroskedastisitas adalah salah satu asumsi dasar regresi linear dimana variabel residual sama untuksemua pengamatan. Apabila terjadi suatu keadaan dimana variabel pengganggu tidak mempunyai varian yang sama untuk semua observasi maka dikatakan model regresi tersebut terdapat suatu gejala heterokedastisitas (Gujarati, 2012). Model regresi yang baik adalah yang homoskedasitas atau tidakterjadi Heteroskedasitas. Berikut hipotesis uji heteroskedastisitasnya :

H0: Probabilitas Chi-Square $>\alpha(5 \%)$, tidak ada heteroskedastisitas

H1 : Probabilitas Vhi-Square $<\alpha(5 \%)$, ada heteroskedastisitas

Berikut hasil uji heteroskedastisitas dengan Breusch Pagan Godfrey yaitu :

Tabel 5 : Hasil Uji Heteroskedastisitas

Heteroskedasticity Test: Breusch-Pagan-Godfrey

\begin{tabular}{lll}
\hline \hline F-statistic & 1.362914 Prob. F(5,38) & 0.2598 \\
Obs*R-squared & 6.690707 Prob. Chi-Square(5) & $\mathbf{0 . 2 4 4 7}$ \\
$\begin{array}{l}\text { Scaled explained } \\
\text { SS }\end{array}$ & 13.23580 Prob. Chi-Square(5) & 0.0213 \\
\hline S
\end{tabular}

Sumber : Hasil Olahan Eviews 9 (2019)

Berdasarkan hasil uji heteroskedastisitas maka dapat dilihat bahwa nilai probabilitas ChiSquare $=0.2447>\alpha=0.05$. Hal ini dapat disimpulkan tidak terjadi heteroskedastisitas pada model regresi.

\section{Hasil Analisis dengan Fixed Effect Model}

Setelah melakukan Uji Chow dan Uji Hausman maka telah ditentukan model yang sesuai yakni Metode Fixed Effect Model. Fixed Effect Model adalah model regresi data panel dengan memperhatikan efek perbedaan dari unit cross section. Sehingga hasil regresi data panel sebagai berikut : 


\section{Tabel 6 \\ Hasil Regresi Fixed Effect Model}

\begin{tabular}{|c|c|c|c|c|}
\hline $\begin{array}{l}\text { Dependent Variable: } \\
\text { Method: Pooled Leas } \\
\text { Date: } 04 / 30 / 19 \text { Time } \\
\text { Sample: } 20082018 \\
\text { Included observation } \\
\text { Cross-sections includ } \\
\text { Total pool (balanced) } \\
\text { White cross-section s }\end{array}$ & $\begin{array}{l}\text { AM? } \\
\text { ares } \\
66 \\
\text { rvations: } 44 \\
\text { ird errors \& cc }\end{array}$ & variance (d.f. c & rrected) & \\
\hline Variable & Coefficient & Std. Error & t-Statistic & Prob. \\
\hline $\begin{array}{c}\text { EPS? } \\
\text { PER? } \\
\text { PBV? } \\
\text { ROE? } \\
\text { DER? } \\
\text { C } \\
\text { Fixed Effects (Cros } \\
\text { BMRI--C } \\
\text { BBRI-C } \\
\text { BBNI-C } \\
\text { BBTN-C }\end{array}$ & $\begin{array}{r}8.767735 \\
60.70747 \\
708.3592 \\
-102.1480 \\
-483.3734 \\
5142.655 \\
\\
1272.873 \\
-451.2182 \\
-746.3222 \\
-75.33256\end{array}$ & $\begin{array}{l}1.298062 \\
56.81470 \\
268.2447 \\
33.45240 \\
144.6824 \\
1529.731\end{array}$ & $\begin{array}{r}6.754479 \\
1.068517 \\
2.640720 \\
-3.053534 \\
-3.340928 \\
3.361804\end{array}$ & $\begin{array}{l}0.0000 \\
0.2926 \\
0.0123 \\
0.0043 \\
0.0020 \\
0.0019\end{array}$ \\
\hline & Effects Sp & ecification & & \\
\hline Cross-section fixed (c & ny variables) & & & \\
\hline $\begin{array}{l}\text { R-squared } \\
\text { Adjusted R-squared } \\
\text { S.E. of regression } \\
\text { Sum squared resid } \\
\text { Log likelihood } \\
\text { F-statistic } \\
\text { Prob(F-statistic) }\end{array}$ & $\begin{array}{r}0.886897 \\
0.861045 \\
1279.740 \\
57320680 \\
-372.1929 \\
34.30665 \\
0.000000\end{array}$ & $\begin{array}{l}\text { Mean depeno } \\
\text { S.D. depende } \\
\text { Akaike info cr } \\
\text { Schwarz crite } \\
\text { Hannan-Quin } \\
\text { Durbin-Watso }\end{array}$ & $\begin{array}{l}\text { ntvar } \\
\text { tvar } \\
\text { erion } \\
\text { on } \\
\text { criter. } \\
\text { stat }\end{array}$ & $\begin{array}{l}5164.091 \\
3433.088 \\
17.32695 \\
17.69190 \\
17.46229 \\
2.157761\end{array}$ \\
\hline
\end{tabular}

Sumber : Hasil Olahan Eviews 9 (2019)

Model persamaan regresi dengan menggunakan pengolahan data panel yang merupakan gabungan antara data time series dan data cross section yaitu :

dimana :

$$
\begin{aligned}
Y_{i t}=5142.655 & +8.767735 X_{1 i t}+60.70747 X_{2 i t}+708.3592 X_{3 i t}-102.1480 X_{4 i t} \\
& -483.3734 X_{5 i t}
\end{aligned}
$$

$$
\begin{array}{ll}
Y_{i t} & =\text { Harga Saham } \\
X_{1} & =\text { Earning per Share } \text { (EPS) } \\
X_{2} & =\text { Price Earning Ratio }(\mathrm{PER}) \\
X_{3} & =\text { Price to Book Value }(\mathrm{PBV}) \\
X_{4} & =\text { Return to Equity } \text { (ROE) } \\
X_{5} & =\text { Debt to Equity Ratio (DER) }
\end{array}
$$

Persamaan regresi dapat diinterpretasikan yaitu :

1. Koefisien hasil regresi menunjukkan angka 5142.655 mempunyai arti bahwa jika EPS, PER, PBV, ROE, dan DER bernilai nol maka harga saham akan mengalami kenaikan sebesar 5142.655.

2. Earning per Share (EPS) menunjukkan angka 8.767735 mempunyai arti bahwa jika PER, PBV,ROE, dan DER konstan maka setiap peningkatan EPS sebesar 1\% akan meningkatkan harga saham sebesar 8.767735 .

3. Price Earning Ratio (PER) menunjukkan angka 60.70747 mempunyai arti bahwa jika EPS, PBV,ROE, dan DER konstan maka setiap peningkatan PER sebesar 1\% akan meningkatkan harga saham sebesar 60.70747 . 
4. Price to Book Value (PBV) menunjukkan angka 708.3592 mempunyai arti bahwa jika EPS, PER,ROE, dan DER konstan maka setiap peningkatan PBV sebesar 1\% akan meningkatkan harga saham sebesar 708.3592.

5. Return to Equity (ROE) menunjukkan angka 102.1480 mempunyai arti bahwa jika EPS, PER, PBV,dan DER konstan maka setiap peningkatan ROE sebesar 1\% akan menurunkan harga saham sebesar 102.1480 .

6. Debt to Equity Ratio (DER) menunjukkan angka 483.3734 mempunyai arti bahwa jika EPS, PER,PBV, dan ROE konstan maka setiap peningkatan DER sebesar 1\% akan menurunkan harga saham sebesar 483.3734.

\section{Pengujian Hipotesis}

Terdapat tiga macam uji hipotesis terhadap koefisien regresi yang dapat dilakukan, yaitu :

a) Uji Signifikansi Parameter (Uji-T)

Uji-T dikenal dengan uji parsial, yaitu untuk menguji bagaimana pengaruh masing-masing variabel bebasnya secara sendiri-sendiri terhadap variabel terikatnya. Hipotesis yang digunakan yaitu :

H0: Variabel bebas tidak mempengaruhi variabel terikat

H1: Variabel bebas mempengaruhi variabel terikat Pada hasil regresi, kondisi yang diharapkan adalah menerima hipotesis $\mathrm{H} 1$ atau variabel bebas mempengaruhi variabel terikat. Berikut ini nilai t-statistik yang diperoleh :

Tabel 7

Hasil Regresi

\begin{tabular}{|c|c|c|c|c|}
\hline Variable & Coef & t-Stat & Prob. & Signifikansi \\
\hline EPS? & 8.767735 & 6.754479 & 0.0000 & Signifikan \\
\hline PER? & 60.70747 & 1.068517 & 0.2926 & Tidak signifikan \\
\hline PBV? & 708.3592 & 2.640720 & 0.0123 & Signifikan \\
\hline ROE? & -102.1480 & -3.053534 & 0.0043 & Signifikan \\
\hline DER? & -483.3734 & -3.340928 & 0.0020 & Signifikan \\
\hline
\end{tabular}

Sumber : Hasil Olahan Eviews 9 (2019)

Berdasarkan tabel 7 diketahui nilai probabilitas masing-masing variabel yaitu :

1) Nilai probabilitas dari Earning per Share (EPS) sebesar 0.0000. Hal ini berarti nilai probabilitas

EPS lebih kecil daripada $\alpha=5 \%$ atau $(0.0000<0.05)$, maka hipotesis $\mathrm{H} 1$ diterima dan dikatakan

EPS berpengaruh signifikan terhadap harga saham.

2) Nilai probabilitas dari Price Earning Ratio (PER) sebesar 0.2926. Hal ini berarti nilai probabilitas PER lebih besar daripada $\alpha=5 \%$ atau $(0.2926<0.05)$, maka hipotesis $\mathrm{H} 1$ ditolak dan dikatakan PER tidak berpengaruh signifikan terhadap harga saham.

3) Nilai probabilitas dari Price to Book Value (PBV) sebesar 0.0123. Hal ini berarti nilai probabilitas EPS lebih kecil daripada $\alpha=5 \%$ atau $(0.0123<0.05)$, maka hipotesis H1 diterima dan dikatakan PBV berpengaruh signifikan terhadap harga saham.

4) Nilai probabilitas dari Return to Equity (ROE) sebesar 0.0043. Hal ini berarti nilai probabilitas

EPS lebih kecil daripada $\alpha=5 \%$ atau $(0.0043<0.05)$, maka hipotesis H1 diterima dan dikatakan

ROE berpengaruh signifikan terhadap harga saham.

5) Nilai probabilitas dari Debt to Equity Ratio (DER) sebesar 0.0020. Hal ini berarti nilai probabilitas EPS lebih kecil daripada $\alpha=5 \%$ atau $(0.0020<0.05)$, maka hipotesis H1 diterima dan dikatakan DER berpengaruh signifikan terhadap harga saham. 
b. Uji Signifikansi Simultan (Uji-F)

Uji F yaitu uji untuk melihat bagaimanakah pengaruh semua variabel penelitian bebasnya secara bersama-sama terhadap variabel terikatnya. Dari hasil regresi, dapat dilihat bahwa nilai probabilitas F-statisticnya sebesar 0.000000 dimana nilai tersebut lebih kecil dari $\alpha=$ 5\% (0.05) sehingga dapat disimpulkan bahwa secara bersama-sama variabel EPS, PER, PBV, ROE, dan DER berpengaruh signifikan terhadap harga saham di 4 bank plat merah. Ini menunjukkan bahwa hipotesis $\mathrm{H} 0$ ditolak dan $\mathrm{H} 1$ diterima.

\section{c. Uji Koefisien Determinasi $\left(\mathbf{R}^{2}\right)$}

Koefisien determinasi $\left(\mathrm{R}^{2}\right)$ digunakan untuk mengukur seberapa jauh kemampuan model dalam menerangkan variasi variabel terikat. Batasan dari nilai koefisien determinasi adalah $0<\mathrm{R}^{2}<1$. Nilai $\mathrm{R}^{2}$ yang semakin mendekati satu dapat dikatakan bahwa model dalam penelitian semakin baik. Nilai Koefisien determinasi $\left(\mathrm{R}^{2}\right)$ yang didapatkan dalam penelitian ini sebesar 0.886897. Hal ini berartibesarnya pengaruh total variabel bebas terhadap variabel terikatnya yakni sebesar 0.886897 atau sekitar $88.69 \%$ dan sisanya sebesar $11.31 \%$ dipengaruhi oleh variabel lain di luar model.

\section{Pembahasan Model Temuan \\ Earning per Share (EPS) terhadap harga saham}

Earning per Share (EPS) berpengaruh positif dan signifikan terhadap harga saham. EPSmenunjukkan kemampuan perusahaan dalam menghasilkan keuntungan bersih dalam setiap lembar sahamnya. Semakin tinggi nilai EPS berarti semakin baik karena akan meningkatkan harga saham dan menguntungkan perusahaan. EPS yang meningkat menandakan perusahaan berhasil meningkatkan taraf kemakmuran investor. Hal ini mendorong investor untuk menambah jumlah modal yang ditanamkan pada perusahaan. Peningkatan jumlah permintaan terhadap saham mendorong harga saham naik.

\section{Price Earning Ratio (PER) terhadap harga saham}

Price earning ratio (PER) tidak berpengaruh signifikan terhadap harga saham. PER merupakanrasio yang menggambarkan apresiasi pasar terhadap kemampuan perusahaan menghasilkan laba.Dengan hasil penelitian ini adanya PER belum mampu mempengaruhi minat investor dalam keputusan menanamkan saham pada perusahaan, investor harus melihat faktor lain yang lebih berpengaruh untuk menanamkan sahamnya sehingga tidak berpengaruh terhadap harga saham.

\section{Price to Book Value (PBV) terhadap harga saham}

Price to Book Value (PBV) berpengaruh positif dan signifikan terhadap harga saham. PBVmencerminkan tingkat keberhasilan manajemen perusahaan dalam menjalankan perusahaan, mengelola sumber daya yang tercermin pada harga saham pada akhir tahun. Semakin tinggi nilai PBV tentunya memberikan harapan para investor untuk mendapatkan keuntungan yang lebih besar sehingga mempengaruhi harga saham yang semakin meningkat.

\section{Return to Equity (ROE) terhadap harga saham}

Return On Equity (ROE) berpengaruh signifikan terhadap harga saham. Kinerja keuanganperusahaan yang diwakili oleh rasio ROE menunjukkan kinerja yang baik karena perusahaan dapat memaksimalkan penggunakan ekuitasnya untuk mencapai tingkat keuntungan tinggi. Hasil penelitian ini sejalan dengan teori dimana apabila semakin besar ROE menunjukkan semakin besar laba bersih yang diperoleh perusahaan. Hal ini tentu akan menarik minat investor untuk membeli saham perusahaan sehingga harga saham semakin tinggi.

\section{Debt to Equity Ratio (DER) terhadap harga saham}

Debt to Equity Ratio (DER) berpengaruh signifikan terhadap harga saham. DER adalah rasiokeuangan yang membandingkan total liabilitas dengan ekuitas. Penelitian ini sejalan dengan 
teori, yakni ketika DER meningkat maka harga saham meningkat dan jika DER menurun maka harga saham menurun. Hal ini digunakan investor dalam membeli saham pada perusahaan.

\section{KESIMPULAN DAN SARAN}

\section{Kesimpulan}

Berdasarkan hasil pengolahan dan analisis data, maka dapat disimpulkan bahwa :

1. Faktor - faktor fundamental yang diwakili oleh variabel EPS, PBV, ROE, dan DER berpengaruh signifikan secara parsial terhadap harga saham, sedangkan variabel PER tidak berpengaruh signifikan secara parsial terhadap harga saham pada Bank-Bank Plat Merah pada tahun 2008-2018.

2. Faktor - faktor fundamental yang diwakili oleh variabel EPS, PER, PBV, ROE, dan DERberpengaruh signifikan secara simultan terhadap harga saham Bank-Bank Plat Merah pada tahun2008-2018.

\section{Saran}

Berdasarkan kesimpulan di atas maka saran-saran yang dapat diberikan melalui hasil penelitian ini yaitu :

1. Bagi investor yang ingin berinvestasi di saham perusahaan subsector perbankan sebaiknya harus mempertimbangkan faktor-faktor fundamental yang dapat dilihat dari laporan keuangannya dan keadaan pasar saham secara umum agar mengetahui harga saham yang dapat menghasilkan keuntungan maksimal.

2. Bagi perusahaan agar harga saham semakin tinggi dan menarik minat para investor sebaiknya optimalisasi kinerja keuangan harus dicapai melalui peningkatan laba bersih seperti dalam penelitian ini, rasio profitabilitas yang paling berpengaruh signifikan.

3. Bagi peneliti selanjutnya diharapkan dapat menambahkan faktor-faktor fundamental seperti rasio-rasio keuangan lain selain rasio yang digunakan dan dapat menambahkan jumlah sampel dalam waktu pengamatan yang lebih lama sehingga nantinya diharapkan hasilnya akan lebih dapat digeneralisasikan.

\section{Daftar Pustaka}

Bank Mandiri. 2008-2018. Laporan Keuangan Tahunan. www.mandiri.co.id. Diakses tanggal 25 April 2019.

Bank Rakyat Indonesia. 2008-2018. Laporan Keuangan Tahunan. www.bri.co.id. Diakses tanggal 25 April 2019.

Bank Negara Indonesia. 2008-2018. Laporan Keuangan Tahunan. www.bni.co.idDiakses tanggal 25 April 2019.

Bank Tabungan Negara. 2008-2018. Laporan Keuangan Tahunan. www.btn.co.idDiakses tanggal 25 April 2019.

Bursa Efek Indonesia. 2008-2018. Data harga saham BMRI, BBRI, BBNI, dan BBTN.

www.idx.go.id. Diakses tanggal 20 April 2019.

Darminto dan Kertahadi. 2011. Analisis Fundamental Internal untuk Menilai Kewajaran Harga Saham dengan Pendekatan Price Earning Ratio (PER). Jurnal Ilmiah Universitas Brawijaya.

Gabriell, Paulina, dan Untu Victoria. 2018. Pengaruh Struktur Modal dan ROA terhadap Harga Saham pada Food And Beverages Industry yang Terdaftar di BEI (Tahun 2014-2016). Jurnal EMBAVol.6 No.4 September 2018, Hal. 2758 - 2767.

Husnan, Suad dan Pudjiastuti, Enny. 2003, Dasar-dasar Manajemen Keuangan. Yogyakarta: UPP AMP YKPM.

Kasmir. 2008. Bank dan Lembaga Keuangan Lainnya. Edisi keenam. Jakarta : PT Raja Grafindo Persada. Lasni dan Ledi. 2009. Analisis Faktor Fundamental dan Resiko 
Sistematik terhadap Harga Saham pada Industri Dasar dan Kimia di Bursa Efek Indonesia (BEI). Skripsi Universitas Gunadarma.

Martina dan Darmawan Arif. 2019. Effect of DER, ROA, ROE, EPS and MVA on Stock Prices in Sharia Indonesian Stock Index. Journal of Applied Accounting and Taxation Vol. 4, No. 1, March 2019,15-22.

Nachowi, D. Nachowi dan Hardius Usman. 2006. Pendekatan Populer dan Praktis Ekonometrika UntukAnalisis Ekonomi dan Keuangan. Jakarta: Lembaga Penerbit Fakultas Ekonomi UniversitasIndonesia.

Sugiyono. 2010. Metode Penelitian Bisnis (Pendekatan Kuantitatif, Kualitatif dan R\&D).Bandung :Alfabeta.

Tandelilin, Eduardus. 2010. Analisis Investasi dan Manajemen Portofolio. Edisi Pertama. Yogyakarta :BPFE - Yogyakarta.

Trenggonowati. 2009. Metodologi Peenelitian Ekonomi dan Bisnis. Yogyakarta : BPFE Yogyakarta. 